\title{
Determinants of Job Satisfaction and its Impact on Employee Performance and Turnover Intentions
}

\author{
Masooma javed \\ Research Scholar, Department of Management Sciences \\ The Islamia University of Bahawalpur \\ Email Id: Masooma.randhawa22@gmail.com \\ Rifat Balouch \\ Research scholar, Department of Management Sciences \\ The Islamia University of Bahawalpur \\ Email Id: rifat.blouch@gmail.com
}

Fatima Hassan

Research scholar, Department of Management Sciences

The Islamia University of Bahawalpur

Email Id: fati.hassan40@gmail.com

Doi:10.5296/ ijld.v4i2.6094 URL: http://dx.doi.org/10.5296/ ijld.v4i2.6094

\begin{abstract}
Job satisfaction - or lack of it - hinges on a productive, accomplishing relationship between staff and management; indeed, the success of any organization depends on staff members who enjoy their jobs and feel rewarded by their efforts. Ultimately, of all the people in the marketplace may suffer the most when this vital success factor is lacking. In earlier ages, many researchers have been directed on job satisfaction but this still remains an issue for many organizations. The ambition of this research paper is to examine the satisfaction level of the employees and helps organizations to know about the elements that influence job satisfaction. Precisely, we acquired employee empowerment and workplace environment as the antecedents to understand their effect on job satisfaction, and further the impact of job satisfaction on job loyalty, job performance and turnover intention. A self-administered questionnaire was used for data collection from several organizations. Convenient sampling technique was used and 200 questionnaires were circulated out of which 150 were nominated for further analysis. SPSS is used for data analysis statistically. The results showed significant positive association of employee empowerment, workplace environment, job loyalty and job
\end{abstract}


performance with job satisfaction. Furthermore, there is a significant negative relationship between job satisfaction and turnover intention. The findings also demonstrate that there is no significant relation of turnover intention with employee empowerment and job performance.

Keywords: Employee empowerment, workplace environment, job loyalty, job performance, job satisfaction and turnover intention.

\section{Introduction}

A prosperous organization struggles to discover that there is a great degree of assurance, collaboration, employee satisfaction, communication and temptation levels among its staff so that they would be more incentivized towards their work responsibilities and attaining overall organizational objectives. Employee job satisfaction is associated with how people perceive, think, and feel their jobs (Spector, 1997). The investigators have defined job satisfaction as the general behavior and employee's attitudes towards his job (Robbins et al., 2010). Keeping morale high among white collar workers can be of great value for every business, how happy employees are more likely to produce more with fewer days off ands tay true to the company. There are many elements involved in enlightening and retaining the employee satisfaction high, which intellectual employers would do fine to execute.

The general purpose of this study is to determine the satisfaction level of the employees and helps organizations to know about the factors that influence employee satisfaction. In this world, most of the organizations conduct surveys and interviews to know about the satisfaction level of employees. Job satisfaction is enjoyable emotional state ensuing from appraisal of one's job and job experience (Locke, 1976). Employee satisfaction or job satisfaction is, quite simply, how content or satisfied employees are with their jobs. According to Lai Wan (2007) satisfaction is an essential aim for any organization to reach. When the satisfaction level of employees increases, then this will results in more returns to the organization. The dissatisfaction of the employees has adverse effects on efficiency and effectiveness of the organization. So studying job satisfaction is one of the most significant areas of organizations setup.

Job satisfaction is a concept that has often been discussed, studied and described. There are several theories regarding the causal link between the yield behavior and motivations. For example, it may well be considered a result of the behavior of the cycle, it can be considered as a cause of behavior, or it can be considered as part of the regulatory system, including the conclusion of the results leads to a decision whether the modifications(Thierry, 1997). The definitions of job satisfaction are influenced by fundamental theories influence. Some definitions are distinct approach, job satisfaction is considered as being composed of satisfaction with various features of the work and the workplace. In this approach, job satisfaction valued at the sum of satisfaction reported by many different characteristics of work and the workplace. Such an assessment provides a perfect picture of the overall employee satisfaction.

Job satisfaction is one more vital work attitude (cp. Heller \& Watson, 2005; Ilies, Wilson, \& 
Wagner, 2009; Van Dyne \& Pierce, 2004). It has been usually defined as an attitudinal evaluative judgment of one's job or job experiences (Ilies et al., 2009). The specific aim of this study is to examine the impact of employee empowerment and workplace environment on job satisfaction and the effect of job satisfaction on job loyalty, turnover intention and job performance. It is an inner state based on measuring the job and job-related experiences with some degree of favor or disfavor.

Job performance generally refers to whether a person performs their job well or not. Job performance is the way employees execute their work. An employee's performance is determined during job performance reviews. A fruitful service firm has invested resources into programs in order to increase job satisfaction and their employees' performance. The turnover intention is the degree to which employees leave the organization. It also reflected being as leaving the company or department (Tett and Meyer).

The further variables like employee empowerment includes that to what range employees are authorized in decision making in their day-to-day activities (Carless, 2004; Haas, 2010). Employee empowerment is a conception linked to motivation and a feeling to improve self confidence among the employees. Workplace environment includes the location of the work, where the employee performs his everyday activities and duties, such as office or site of construction. Generally other factors like, fresh air, refreshment, noise level and the incentives e.g. child care, also become a part of workplace environment. According to Allen and Grisaffe (2001), loyalty is a psychological state and it illustrates the association of an employee with the organization for which they work and that has implications for their decision to stay with the organization.

As far as our vision is concerned, the emphasis of this research paper is to discover the main factors that help to create the concern of employees towards his job. So, this study will help the supervisors and organizations to better understand about the satisfaction level of employees and how they can encourage their employees to carry out their job proficiently and effectively.

\section{Literature Review}

\section{Job Satisfaction}

Employee job satisfaction has been interconnected with how people think, feel and observe their jobs (Spector, 1997).It is widely used in the field of human resources, who thought that the internal and external features are elements work satisfaction reports(Chang, 1999). In other words, job satisfaction, it is satisfying emotional state as a result of damage assessment of the occupation or the experience of a job(Locke, 1976). According to Rainey(1997), is widely studied organizational job satisfaction survey, all which variable related to how people feel about their jobs and different aspects of their work. This really is the extent to which people like or dislike their work (Spector, 1997).Le'vy- Garboua and Montmarquette (2004) defined employee satisfaction as "a directory of inclination for the practiced career against outside chance provisional on information accessible at time".

Employee job satisfaction is known as assemble that has often been described, discussed and 
researched. There are many presumptions regarding the causal relationship between motives, behavior and proceeds. Employee satisfaction is the measure that tells about employee's general emotion about its workplace and job. It measures his approach towards the job and the extent to which the job is gratifying the employee's needs. It is concluded by many researchers that, to measure the intentions of an employee towards their workplace the satisfaction level of employees is used (Sweeney et al, 2002; Cranny et al., 1992). Numerous factors have been resolute by the researchers like enthusiastic behavior, hygiene factors, managerial responsibility and workplace environment by building on different theories, (Darrow, 1971; Igalens and Roussel, 1999; Brewer et al, 2008; Ahsan et al, 2009; Kuo et al, 2007;).

In literature, a number of practices have been done for the satisfaction of employees. The most important to which is the Maslow's hierarchy of need. In this theory, he suggests that individual needs starts from the basic need (food, cloth and shelter) and ends at the level of self-actualization. Researchers such as Kuhlen (1963) and Conrad et al. (1985), approached to find the factors affecting the satisfaction of employee based on the theory of necessity.

\section{Job Loyalty}

According to Allen and Grisaffe(2001), loyalty is a mental state and illustrates the association of employees with the organization for which they work, and that influences their decision to remain with the organization. According to the description Mathieu and Zajac(1990),establishing the organization, which can be considered a response exciting, especially when the employee believes the values and goals of the organization, and a strong desire to maintain a relationship with an organization called loyalty. Beckeret al.(1995)defines a strong desire to remain a member of the willingness of the organization to establish a high level of effort for of the organization and a clear belief and acceptance of the values and goals of the organization. Therefore, characterize as a belief that plays positive role in maintaining the member of the organization. Strong membership retention of employees in the organization of their organization can be described as" the relative strength of individual recognition and disseminationlaparticular organization" (Wu and Norman, 2006), If satisfaction is a specific characteristic of valid responses and attitudes in work, an effective response to the entire organization is the involvement of employees(Chen, 2006). As suggested by empirical data, job satisfaction is a precursor of loyalty to the organization. This shows that loyalty, employee satisfaction the organization of work and the real fidelity mediator satisfaction variables turnover (Chen2006). There is a positive relationship between employee satisfactions, loyalty and organizational working employees (Fletcherand Williams, 1996). According to Martensen and Gronholdt(2001), employee satisfaction positively correlated with employee loyalty to their company. Furthermore, studies such as Al-Aamer (2000) and Fang(2001)still have a strong correlation between organizational loyalty of employees and job satisfaction of employees (Wu and Norman, 2006). Low job satisfaction leads to low morale, low loyalty to the organization and an increase in sales jobs (Soler, 1998).It would also lead to low employee job satisfaction retreat from their job hunt for a new job or a change. Their current work and career satisfied employees are more organizational loyalty than their work disillusioned workers (Kim etal., 2005).some 
researchers, such asFisher(2000) andLocke(1976) havesimilar results(Petty etal., 2005)found. The degree of organizational loyalty increases with the increase of job satisfaction.

H1: There is a positive relationship between job satisfaction and employee's loyalty.

\section{Workplace Environment}

The location of the work, where the employee performs his duties and daily activities, such as office or site of construction, is included in workplace environment. Generally other factors like, noise level, fresh air, refreshment and the incentives e.g. child care, also become a part of workplace environment. Workplace environment may have either positive or negative impact on the satisfaction level of employees depending upon the nature of working environment. The employees can perform better if they are provided good environment. The working outcomes are directly interlinked with working environment; the more it (environment) is conducive the better the outcome will be. Employee satisfaction plays an important part in the success of organization. The employees will perform better if they are provided good environment. There are various aspects of the physical environment satisfaction that contribute in employee's satisfaction. Researchers asked the question from the employees that may include that how much you are satisfied with your working environment. When an employee is given higher level of satisfaction then it reduces turnover and in turn enhances the morale of an employee (Dole and Schroeder (2001). Carlopio (1996) found that satisfaction with workplace is optimistically associated with job accomplishment and it is indirectly connected with turnovers for better future, Carlopio, (1996); Sandstorm et al. (1994); Leather et al. (2003); Lee and Brand, (2005). The current workplace environment of various organizations has positive association with satisfaction of employees.

H2: Satisfaction with the workplace environment has positive impact on job satisfaction.

\section{Turnover Intention}

The turnover intention is measured the leave-taking of the company or department (Tett \& Meyer, 1993). Turnover intention is an instant ancestor to actual turnover (Johnston, Futrell, Parasuraman, \& Sager, 1988). As per some scholars, turnover can be predicted by personal behavior, (Michaels \& Spector, 1982; Lee \& Mowday, 1987; Abrams, Ando, \& Hinkle, (1998). Employee's satisfaction shows a pessimistic relationship with employee turnover intention (Muchinsky \& Morrow,). When employees are delighted with their job then turnover ratio decreased in the organization and when the employee is not given his rights when he is not contented with his job then the intention of turnover increased with their jobs. There is pragmatic that performance andjob satisfactionare negativelyrelated to theintentionto escape. For example,Boshoffand Allen (2000) found that exerciseeffective use ofemployeesdecreasedtheir intention toleave the organization.Viator(2001) reported that performancewaspessimismassociated with theoriginal plans.In addition,Martin(1979) showed that job satisfactionhasunforgettablenegative impact onturnoverintentionsofa sample 
ofservice.Tettand Meyer (1993) in their investigationmeta-analysis showed that job satisfactionwassignificant salesanalyst.

\section{H3: Job satisfaction is negatively related to employees' intentions to leave the organization.}

\section{Employee Empowerment}

Strengthening theconcept ofempowermentis derivedfromalienation.It isproposedformof participation(Wilkinson, 1998) and refers tothe extent to whichemployees areencouraged to takea firm decision, withoutconsultationwiththeir managerssothat the organizationaldynamicsinitiated atthe bottom (Michailova, 2002). Empowermentpracticeto divide thepowerof participationin decision-making(Carless, 2004), thisaspect concerns thedecisionofthe leadership behavior(Lee andKoh, 2001), andthereforecanbedefined as thestrengthening ofthe building, whichhasdelegatedmanagementby providingemployees withauthority andautonomy overtheirtasks(Hsieh andChao,2004).Empowermentmeansto create valuefor employeesaccordingtotheir own procedureswithoutconstant interventionwork(Ampofo-Boateng et al, 1997). VeltHouse(1990) defines as "theempowermentofemployees' confidence intheir ability todeal withthe selection.Decisionemployees of thetargetto developorganizational and individualperformanceandhelpemployees achieveby allowingemployees tomake their own decision. Theobjectivesof theiremployeeson their work, andfind theproblemsrelated to their work(Juneet al, 2006; Seibertet al, 2004) to solve.From the pointof view of employees, a sense of empowerment has positive effect onjob satisfaction(Snipes et al., 2005). The authorization of worker covers an extensive circle of schedule activities and the mode the authorization activities are undertaken according to its inside that were grown, it is linked to satisfaction of employees that they will get. The power which is taken from isolation, freedom of individual activities, shared administrative and quality of job (Eccles, 1993; Spreitzer et al., 1999) and is prevalent (Bartunek and Spreitzer, 2006), apprehends a form of employee's active contribution program (Wilkinson, 1998) and encourages the employee to make independent decisions without the advice of their supervisors. Hence, the administrative manners are commenced from the bottom to infuse confidence among the employees (Michailova, 2002). Research has consistently shown positive impact of empowerment on outcomes such as job satisfaction.

Empowerment can be effected by turnover intention. A conscious and intentional willfulness to quit an organization is called turnover intention (Meyer and Tett;1993). This can be explainedas a psychologicalresponse to specificorganizational conditionsthat are part ofacontinuum ofbehaviorresignation ofthe organization of thephysical actof turnoverdream(Kraut, 1975). In addition,oncethe decision toquit her jobis notimpulsive, butthisis a decision thathas been designedfor a whilebeforetaking action(Barak et al., 2001). Therefore, the objective of revenueforthe saleprimaryimmediate effectand expresses itsintention to leaveisthe best predictor ofactual turnoverofmany scientists(Barak et al, 2001Bruvold2003andLeeet al. (Kiyak1997GriffethandHom,1991).Presumablysatisfied 
employeesarelikely to spendmore energy, talent and time asa way to demonstratereciprocity andmaintain a close relationshipwiththeir organizationand are less likelyto leave the organization(Boshoff andMels, 21995, Siu, 2002; Rizwan et al., 2013). Therefore, itis to strengthen thepositive attitude, whichin turn woulddecreaseforsales. Thus, using the above discussion we hypothesize:

\section{H4: Employee Empowerment has positive impact on job satisfaction.}

H5: There is a negative relationship between employee empowerment and turnover intention.

\section{Job Performance}

From the perspective ofthejudgeswithHerseyandBlanchard (1993) thelevel of achievement ofbusinessandsocial objectivesto measurejob performanceandaccountability). PorterandLawlersay, 5 (1968), there are threetypes of transactions.Oneof themis ameasure of the amountof salesin a given timeperiod, the output frequency andproductiongroups of employeesreportingmanager, andso on.The secondtype of evaluationperformance evaluationof individualsaffectedpersons other thanthose whoseperformance is consideredsomeone.The thirdmethod ofperformance evaluation isself-evaluationandself-evaluation. The studies show that job performance ispositively related with job satisfaction. There is high demand of trained, highly skilled and qualified employees in labor market. The output and yield of an organization is calculated in terms the performance of its workforce (Currall et al., 2005). It was originate that if an employee is showing better performance then it is due to level of job satisfaction (1977) have investigated the important employee performance indicators at the hiring stage. They concluded that the employee's productivity is affected by level of job satisfaction and motivation. For high performer employees demands attractive packages from the employers. And now it has becomedilemma for the human resource experts to retain the performer (Sumita, 2004). The employee commitment is adversely effected by the low level of employee satisfaction and sequentially it effects the achievement of organizational objectives and performance (Meyer, 1999).

There is empirical support that intention to leave is negatively related to performance and job satisfaction.For example,Boshoffand Allen (2000) found that the performance ofrecovery of valuableservicesof employees decreasedtheir intention toleave the organization.Viator(2001) reported that performance wasnegatively associatedwiththeoriginal intentions.

H6: The job satisfaction positively affects the employee's job performance.

H7: Job Performance has a negative impact on employees' intentions to leave the organization. 


\section{Proposed Model}

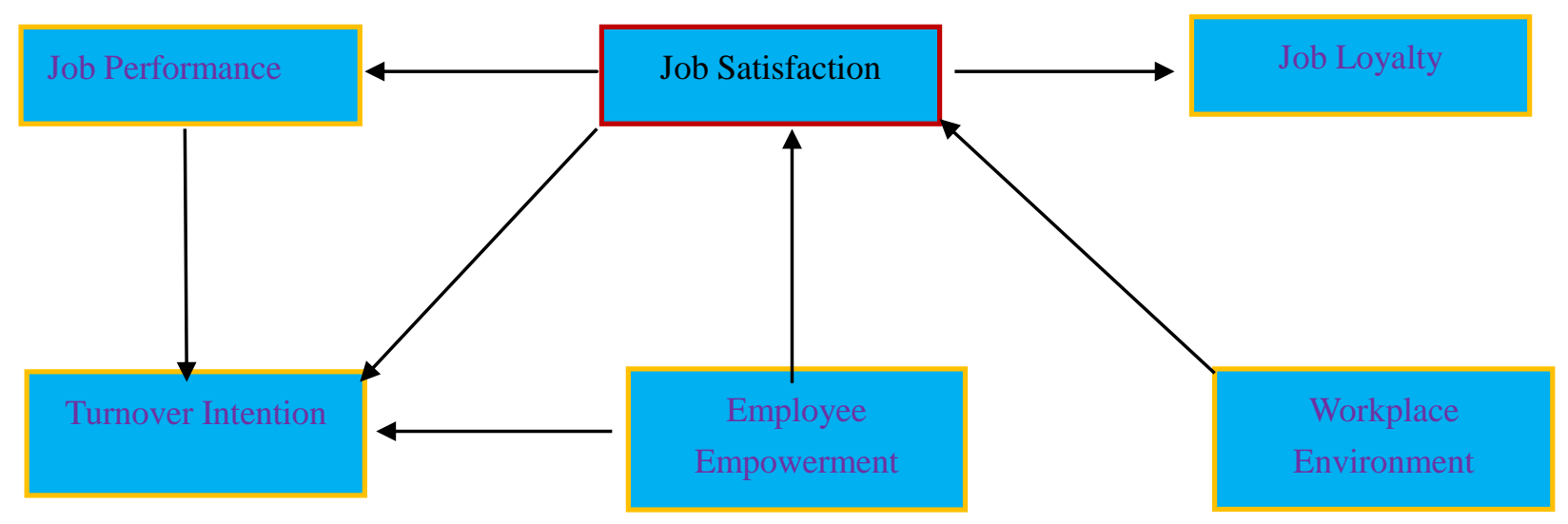

\section{Research Methodology}

This existing study is descriptive in its nature. Well, descriptive research can be defined as describing some particular situation, some phenomena or something. Descriptive researches are those which define the current situation instead of inferring and making judgments (Creswell, 1994). The core goal of the descriptive research is to verify the developed hypotheses that reveal the current situation. This kind of research offers information about current scenario and emphasis on the elements that effect the job satisfaction.

\subsection{Sample/Data}

In order to gather data for understanding job satisfaction, a sample of 200 respondents will ask to take part in a self-administered questionnaire. The inhabitants for the current study are employees in Bahawalpur.

The present research uses a non-probability sampling technique that is convenience sampling. Convenience sampling is a procedure that gains and gathers the appropriate information from the unit of study or sample that are suitably accessible (Zikmund, 1997). Convenience sampling is usually used for gathering a huge number of accomplished surveys rapidly and with economy (Lym etral, 2010).

It has certified that the sample members own one core qualification to take part in the self-administered survey. The sample member should be working as an employee in an organization and having adequate knowledge about its job. We select these sample participants from various organizations in Bahawalpur. The main target to collect sample data was university employees, bankers' and schools employees. The selections of these employees are based on the previous outcomes of the studies on job satisfaction.

\subsection{Instruments and Measures}

The survey instrument of the current research address two important objectives: First is to examine the relationship of different variables with employee job satisfaction. Second, to 
gather information about the various characteristics of the respondents that can be used to comprehend the deviations in different classes.

The survey instrument encloses two sections. Section 1 contains different personal and demographic variables. This section will attain the respondent's information about gender, age, tenure, income and education.

Section 2 consists of the latent variables that are significant in the present research. These variables include employee empowerment, workplace environment, job performance, and turnover intention and job loyalty towards job satisfaction. This segment of the study is developed based on the previous researches and already used questionnaires (Table 1).

The scales of the research were obtained from the past literature and published studies. The first variable of the study is job satisfaction having five items and this scale was taken from Hackman and Oldham (1975). The Second variable is employee empowerment having four items, was taken from Hackman and Oldham (1975). The third variable is workplace environment having five items, was taken from Lee (2006). The fourth variable is job performance having three items and was taken from Bowra et al., (2011). The next variable is turnover intention having four items, was taken from Bluedorn (1982). The last variable is job loyalty with six factors and this scale was taken from Chen Z.X., Farh J.L., Tsui A.S., (1998).

Table 1: scales of the study

\begin{tabular}{|c|c|c|c|}
\hline NO. & Variable & Items & Reference \\
\hline 1 & Job Satisfaction & $\begin{array}{l}\text { 1. My basic salary is sufficiently paid } \\
\text { according to my daily working hours and } \\
\text { work load } \\
\text { 2. I am satisfied with my chances for salary } \\
\text { increases } \\
\text { 3. The work I do is appreciated } \\
\text { 4. I believe those that do well on the job have } \\
\text { fair chances of being promoted } \\
\text { 5. It is possible to get promoted fast in my } \\
\text { job }\end{array}$ & $\begin{array}{l}\text { Hackman } \\
\text { and Oldham } \\
(1975)\end{array}$ \\
\hline 2 & $\begin{array}{l}\text { Employee } \\
\text { Empowerment }\end{array}$ & $\begin{array}{l}\text { 1. I have the authority to correct daily } \\
\text { problem when they occur } \\
\text { 2. I am encouraged to handle daily problems } \\
\text { by myself }\end{array}$ & $\begin{array}{l}\text { Hackman } \\
\text { and Oldham } \\
(1975)\end{array}$ \\
\hline
\end{tabular}




\begin{tabular}{|c|c|c|c|}
\hline & & $\begin{array}{l}\text { 3. I have control over how I solve daily } \\
\text { problems } \\
\text { 4. I am able to control the social contact with } \\
\text { others }\end{array}$ & \\
\hline 3 & $\begin{array}{l}\text { Workplace } \\
\text { Environment }\end{array}$ & $\begin{array}{l}\text { 1. I am able to personalize my workspace } \\
\text { 2. My work area has many visual distractions } \\
\text { 3. My workstation is large } \\
\text { 4. I am able to determine the } \\
\text { organization/appearance of my work area } \\
\text { 5. My workplace provides an undisturbed } \\
\text { environment }\end{array}$ & Lee (2006) \\
\hline 4 & Job Performance & $\begin{array}{l}\text { 1. My performance is better than that of my } \\
\text { colleagues with similar qualifications } \\
\text { 2. I am satisfied with my performance } \\
\text { because it is mostly good } \\
\text { 3. My performance is better than that of } \\
\text { employees with similar qualifications in } \\
\text { other organizations }\end{array}$ & $\begin{array}{l}\text { Bowra et } \\
\text { al., }(2011)\end{array}$ \\
\hline 5 & Turnover Intention & $\begin{array}{l}\text { 1. I often think about quitting } \\
\text { 2. It is likely that I will actively look for a } \\
\text { new job next year } \\
\text { 3. I will probably look for a new job in the } \\
\text { next year } \\
\text { 4. I often think of changing my job }\end{array}$ & $\begin{array}{l}\text { Bluedorn } \\
\text { (1982) }\end{array}$ \\
\hline 6 & Job Loyalty & $\begin{array}{l}\text { 1. I want to continue my work in the same } \\
\text { organization } \\
\text { 2. I would like to advise my friends to do } \\
\text { work in this organization } \\
\text { 3. When somebody speak ill of my } \\
\text { organization, I will defend it immediately }\end{array}$ & $\begin{array}{ll}\text { Chen } & \text { Z.X., } \\
\text { Farh J.L., } \\
\text { Tsui } \\
\text { (1998) }\end{array}$ \\
\hline
\end{tabular}




\begin{tabular}{|l|l|}
\hline 4. I would support my organization in almost \\
any \\
5. $\begin{array}{l}\text { No matter whether it will benefit me or } \\
\text { not, I will be willing to continue working } \\
\text { under my organization }\end{array}$ \\
$\begin{array}{l}\text { 6. When someone praises my organization, I } \\
\text { feel like a personal compliment }\end{array}$
\end{tabular} \mid

\subsection{Procedure}

The questionnaire was circulated among 200 respondents in Bahawalpur. These respondents are chosen based on the criteria above stated. Before giving the questionnaire, the objective of study and questions were described to the respondents so they can easily fill the questionnaire with appropriate responses. A total of 150 questionnaires were selected and rest of the questionnaires was not included in the further analysis due to half-finished or worthless responses. After collecting the completed questionnaires from employees of various organizations, these questionnaires were entered into the SPSS sheet for further analysis.

\subsection{Reliability Analysis}

The Cronbach's alpha of job satisfaction questionnaire items is more than acceptable and recommended value 0.50 by Nunnally (1970) and 0.60 by Moss et al. (1998). This displays that all the 27 items were reliable and valid to measure the attitudes of employees towards job satisfaction.

Table 2: Reliability of dimensions Instrument

\begin{tabular}{|l|l|l|}
\hline Scales & Items & Cronbach Alpha \\
\hline Job Satisfaction & 5 & 0.760 \\
Employee Empowerment & 4 & 0.712 \\
Workplace Environment & 5 & 0.635 \\
Job Performance & 3 & 0.671 \\
Turnover Intention & 4 & 0.872 \\
Job Loyalty & 6 & 0.821 \\
\hline
\end{tabular}




\subsection{Results and Analysis}

\section{Profile of the Respondents}

Personal and demographic information such as age, gender and tenure, income and education are presented in the following table (Table 3).

Table 3: Profile of the Respondents

\begin{tabular}{|c|c|c|c|}
\hline & Category & Frequency & Percentage \\
\hline Variable & & & \\
\hline Gender & $\begin{array}{l}\text { Male } \\
\text { Female }\end{array}$ & $\begin{array}{l}68 \\
82\end{array}$ & $\begin{array}{l}45.3 \\
54.6\end{array}$ \\
\hline Age & $\begin{array}{l}\text { 15-20 years } \\
20-25 \text { years } \\
25-30 \text { years } \\
30-35 \text { years } \\
35-40 \text { years } \\
\text { Above } 40 \text { years }\end{array}$ & $\begin{array}{l}3 \\
50 \\
52 \\
30 \\
10 \\
5\end{array}$ & $\begin{array}{l}2 \\
33.3 \\
34.6 \\
20 \\
6.6 \\
3.3\end{array}$ \\
\hline Tenure & $\begin{array}{l}\text { Less than } 1 \text { year } \\
1-3 \text { years } \\
\text { 3-5 years } \\
5-10 \text { years } \\
\text { More than } 10 \text { years }\end{array}$ & $\begin{array}{l}34 \\
45 \\
28 \\
32 \\
11\end{array}$ & $\begin{array}{l}22.6 \\
30 \\
18.6 \\
21.3 \\
7.3\end{array}$ \\
\hline Income (Rs/month) & $\begin{array}{l}\text { Below } 15000 \\
15000-25000 \\
25000-35000 \\
35000-45000 \\
45000-55000\end{array}$ & $\begin{array}{l}59 \\
33 \\
20 \\
19 \\
16\end{array}$ & $\begin{array}{l}39.3 \\
22 \\
13.3 \\
12.6 \\
10.6\end{array}$ \\
\hline
\end{tabular}




\begin{tabular}{|l|l|l|l|}
\hline & Above 55000 & 3 & 2 \\
\hline Education & Matriculation & 3 & 2 \\
Inter & 1 & 0.6 \\
Bachelors & 45 & 30 \\
Master & 82 & 54.6 \\
MS/M.Phil. & 18 & 12 \\
PHD & 1 & 0.6 \\
\hline
\end{tabular}

\section{Hypothesis Testing}

\section{Job loyalty and Job satisfaction}

According to the result of the study job loyalty (JL) has a significant positive association with Job satisfaction (JS) with $\beta=0.415$ and $\mathrm{P}=0.000$ that means the job satisfaction contributes more than $41 \%$ to Job loyalty. So, we accept the hypothesis 1 .

\section{Work place environment and Job satisfaction}

According to the result of the study workplace environment (WPE) has a significant positive association with JS with $\beta=0.169$ and $\mathrm{P}=0.045$ that means the WPE contributes more than $16 \%$ to JS. So, we accept the hypothesis 2 .

\section{Turnover intention and Job satisfaction}

According to the result of the study job satisfaction (JS) has a significant negative relationship with Turnover Intention (TOI) with $\beta=-0.321$ and $\mathrm{P}=0.000$ that means the JS contributes more than $32 \%$ to TOI. These results validate the hypothesis 3 .

\section{Employee empowerment and Job satisfaction}

According to the result of the study employee empowerment (EE) has a significant positive association with job satisfaction (JS) with $\beta=0.375$ and $P=0.000$ that means the EE contributes more than $37 \%$ to JS. So these results of study validate the hypothesis 4 .

\section{Employee empowerment and Turnover intention}

While considering the significance between turnover intention and employee empowerment, the result of current studies shows no significant relationship between these variables with $\beta$ $=-0.101$ and $\mathrm{P}=0.242$, according to this $\mathrm{EE}$ contributes only more than $10 \%$ to TOI. So, we will reject the hypothesis 5 .

\section{Job satisfaction and Job performance}

Regression analysis result shows that job satisfaction found significantly related with job 


\section{Macrothink}

International Journal of Learning \& Development

ISSN 2164-4063

2014, Vol. 4, No. 2

performance. There is significant positive relationship between job satisfaction and job performance with $\beta=0.114$ and $\mathrm{P}=0.01$, it means JS contributes more than $11 \%$ to JP. Thus, these results validate the hypothesis 6 .

\section{Job performance and Turnover intention}

While considering the significance between turnover intention and job performance, the result of current studies shows no significance relation between these variables with $\beta=$ 0.099 and $\mathrm{P}=0.198$ and it indicates that JP contributes only more than $9 \%$ to TOI. So we will reject the hypothesis 7 .

Table 4: Regression Results

\begin{tabular}{|l|l|l|l|l|l|l|}
\hline Hypothesis & Model variables & Estimate & S.E & C.R & P & Results \\
\hline H1 & J.S $\rightarrow \quad$ J.L & 0.415 & 0.67 & 5.543 & 0.000 & Supported \\
\hline $\mathrm{H} 2 \mathrm{~N}$ & $\begin{array}{l}\text { WPE } \\
\text { J.S }\end{array}$ & 0.169 & 0.108 & 2.019 & 0.045 & Supported \\
\hline $\mathrm{H} 3$ & $\begin{array}{l}\text { J.S } \\
\text { TOI }\end{array}$ & -0.321 & 0.101 & -3.729 & 0.000 & Supported \\
\hline $\mathrm{H} 4$ & $\begin{array}{l}\text { E.E } \\
\text { J.S }\end{array}$ & 0.375 & 0.095 & 4.484 & 0.000 & Supported \\
\hline H5 & $\begin{array}{l}\text { E.E } \longrightarrow \\
\text { TOI }\end{array}$ & -0.101 & 0.115 & -1.176 & 0.242 & $\begin{array}{l}\text { Not } \\
\text { supported }\end{array}$ \\
\hline H7 & $\begin{array}{l}\text { J.S J.P } \\
\text { J.P } \longrightarrow\end{array}$ & 0.114 & 0.062 & 2.539 & 0.01 & Supported \\
\hline
\end{tabular}




\section{Structural Model Result}

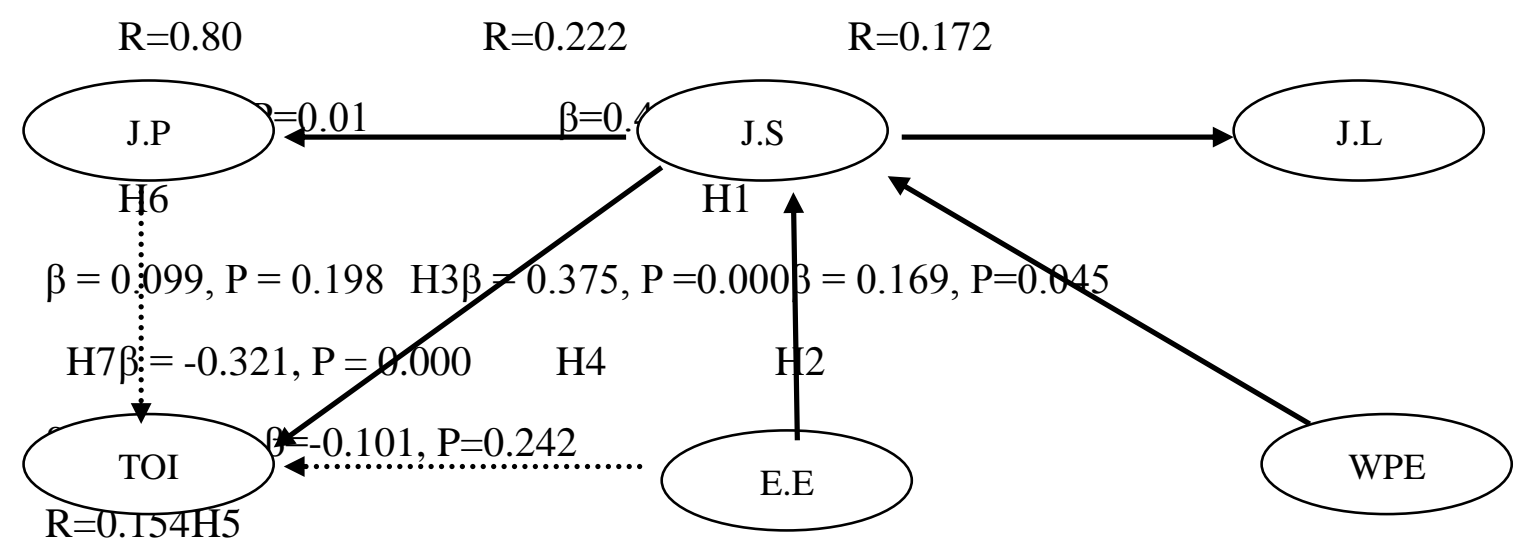

\section{Significant \\ Insignificant}

\section{Discussion}

This research has been conducted in the private sector as well as in public sector organizations of Bahawalpur City. The main objective of this research is to know the factors that have effect on job satisfaction in any organization. We analyze many of past researches and choose the variables from that research papers to find their effect on the organizations in Bahawalpur City. This research also ensures that is there any correlation in job satisfaction and employee turnover intention, employee empowerment, job loyalty, job performance and workplace environment?

We conducted this research by taking the sample of 200 employees from target population. 150 of the employees responded to our questionnaire. Our research consists of two parts; in the first part we collect the personal information from employees of different organizations about gender, age, income, education and status. In the second part once we use employee empowerment and workplace environment as independent variables and job satisfaction as a dependent variable, after that we took job satisfaction as independent variable and turnover intention, job loyalty and job performance as dependent variables. We conducted analysis on the data collected from the samples. The results show that EE has a significant positive relationship and it contributes more than $37 \%$ to JS. Therefore, when an employee is given autonomy in business decisions then his satisfaction level will rise, but EE has negative relation with TOI, and EE contributes less than $1 \%$ to turnover intention so it means that besides EE there are other more influential factors on turnover intention. Similarly, work place environment has a positive relation with JS and it contributes $16 \%$ to JS. As it has a positive impact on job satisfaction so it shows that when an employee is given favorable and clean environment then its satisfaction level rises. 
After that we analyze the relationship between job satisfaction and employee turnover intentions means intention towards leaving the organization. Whenever there is low level of employee satisfaction in any organization, the employees of that organization will intentionally leave that organization. According to the result of the study, JS has a significant negative relationship with TI contributing more than $32 \%$ to TOI. Our next variable is job loyalty, according to the result of the study JL has noteworthy positive relationship JS contributing more than $41 \%$ to JS. It shows that satisfied employees have greater Organizational loyalty than those who are not satisfied with their jobs (Kim et al., 2005). Also, low job satisfaction could cause employees to move away from their jobs, search for new jobs, or change their existing jobs and careers. The degree of organizational loyalty of employee is higher when employee job satisfaction increased. Our last variable is job performance and the above studies shows that job satisfaction has the impact on job performance; according to the result of our studies JP contributes $14 \%$ to JS. It shows that level of job satisfaction and motivation affects the employee's productivity. The high performer demand attractive package from the employers, but job performance is negatively related to the turnover intention. JP contributes $9 \%$ to the turnover intention but the regression result shows that job performance has no significant relation with turnover intention because $\mathrm{P}$ is greater than 0.05 , these result rejects the hypothesis.

\section{Limitations and Future Research}

This research paper has several limitations. First, this study considered only few factors of job satisfaction like job performance, employee empowerment, job loyalty, turnover intention and work place environment. Secondly, the sample size of the study is small which should be increased in order to understand the most important determinants at more generalized level. Thirdly, the data is collected from a particular group of people. In future, the light should shed on other variables like reward and recognition, training and development, and organizational commitment which need to be discussed for further understanding of job satisfaction.

\section{References}

1. Al-Aameri, A.S. (2000), "Job satisfaction and organizational commitment for nurses",Saudi Medical Journal, Vol. 21 No. 6, pp. 531-5.

2. Ampofo-Boateng, K., Merican, W.R.A., Jamil, A. and Wiegand, B. (1997), "Employees' adaptation to technological changes in a multinational corporation in Malaysia, innovation in technologymanagement - the key to global leadership", PICMET'97: Portland. International Conference on Management and Technology, Portland, 27-31 July, pp. 987-9.

3. Bartunek, J.M. and Spreitzer, G.M. (2006), "The interdisciplinary career of a popular constructused in management - empowerment in the late 20th century", Journal of ManagementInquiry, Vol. 15, pp. 255-73. 
4. Barak, M.E.M., Nissly, J.A. and Levin, A. (2001), “Antecedents to retention and turnover amongchild welfare, social work, and other human service employees: what can we learn frompast research? A review and metanalysis", Social Service Review, Vol. 75, pp. 625-61.

5. Becker, T.E., Randal, D.M. and Riegel, C.D. (1995), "The multidimensional view of commitmentand theory of reasoned action: a comparative evaluation", Journal of Management, Vol. 21No. 4, pp. 617-38.

6. Boshoff, C. and Mels, G. (1995), "A causal model to evaluate the relationships among supervision,role stress, organizational commitment and internal service quality", European Journal ofMarketing, Vol. 29, pp. 23-42.

7. Boshoff, C., \& Allen, J. (2000). The influence of selected antecedentson frontline staff's perceptions of service recovery performance. International Journal of Service Industry Management, 11(1), 63-90.

8. Carless, S.A. (2004), "Does psychological empowerment mediate the relationship betweenPsychological climate and job satisfaction?” Journal of Business and Psychology, Vol. 18No. 4, pp. 405-25.

9. Z. X. Chen, A. S. Tsui and J. L. Farh, "Loyalty to Supervisor versus Organizational Commitment: Relationships to Employee Performance in China," Journal of Occupational Organization, Vol. 75, 2002, pp. 339-356.

10. Cranny, C.J., Smith, P.C. and Stone, E.F. (1992), Job Satisfaction: How People Feel about Their Jobs and How It Affects Their Performance, Lexington, New York, NY.

11. Chen, C. (2006), "Job satisfaction, organizational commitment, and flight attendants' turnoverintentions: a note", Journal of Air Transport Management, Vol. 12, pp. 274-6.

12. Currall SC, Towler AJ, Judge, TA, Kohn, (2005). Pay satisfaction andorganizational outcomes. Personnel Psychol., 58: 613-640.

13. Conrad, K.M., Conrad, K.J. and Parker, J.E. (1985) "Job satisfaction among occupational health nurses", Journal of Community Health Nursing, Vol. 2, pp. 161-73.

14. Carlopio, J.R. (1996), "Construct validity of a physical work environment satisfaction questionnaire”, Journal of Occupational Health Psychology, Vol. 1 No. 3, pp.330-44.

15. Creswell, J. W. (1994). Research designs: Qualitative and quantitative approaches. Thousand Oaks, CA: Sage.

16. Chang, E. (1999), "Career commitment as a complex moderator of organizational commitmentand turnover intention”, Human Relations, Vol. 52 No. 10, pp. 1257-78.

17. Darrow, L.E. (1971), "Empirical test of the Herzberg two-factor theory of job satisfaction", unpublished doctoral dissertation, East Texas State University, Commerce, TX. 
18. Dole, C. and Schroeder, R.G. (2001), "The impact of various factors on the personality, job satisfaction andturnover intentions of professional accountants", Managerial Auditing Journal, Vol. 16 No. 4, pp. 234-45.

19. Eccles, T. (1993), “The deceptive allure of empowerment”, Long Range Planning, Vol. 26,pp. 13-21.

20. Fang, Y. (2001), "Turnover propensity and its causes among Singapore nurses: an empiricalstudy", International Journal of Human Resource Management, Vol. 12 No. 5, pp. 859-71.

21. Fisher, C.D. (2000), "Mood and emotions while working: missing pieces of job satisfaction?”,Journal of Organizational Behavior, Vol. 21, pp. 185-202.

22. Fletcher, C. and Williams, R. (1996), "Performance management, job satisfaction andorganizational commitment", British Journal of Management, Vol. 7 No. 2, pp. 169-79.

23. Heller, D., \& Watson, D. (2005). The dynamic spillover of satisfaction between work andmarriage: The role of time, mood and personality. Journal of Applied Psychology, 90(6), 1273-1279.

24. Hackman, J.R. and Oldham, G.R. (1975), "Development of the job diagnostic survey", Journal ofApplied Psychology, Vol. 60, pp. 159-70.

25. Hsieh, A.T. and Chao, H.Y. (2004), “A reassessment of the relationship between job specialization, job rotation and job burnout: example of Taiwan's high-technologyindustry", International Journal of Human Resource Management, Vol. 15, pp. 1108-23.

26. Hersey, P. and Blanchard, K.H. (1993), Leadership Style: Attitudes and Behaviors, Prentice Hall,Englewood Cliffs, NJ.

27. Johnston, M. W., Futrell, C. M., Parasuraman, A., \& Sager, J. (1988). Performance and job satisfaction effects on salesperson turnover: A replication and extension. Journal of Business Research, 16(1), 67-83.

28. Kim, W.G., Leong, J.K. and Lee, Y. (2005), "Effect of service orientation on job satisfaction,organizational commitment and intention of leaving in a casual dining chain restaurant”,Hospitality Management, Vol. 24, pp. 171-93.

29. Kiyak, H.A., Namazi, K.H. and Kahana, E.F. (1997), “Job commitment and turnover amongwomen working in facilities sewing older persons", Research on Aging, Vol. 19, pp. 223-46.

30. Kraut, A.I. (1975), "Predicting turnover of employees from measured job attitudes", Organizational Behavior and Human Performance, Vol. 13, pp. 233-43.

31. Kuhlen, R.G. (1963), "Needs, perceived need satisfaction opportunities, and satisfaction with occupation”, Journal of Applied Psychology, Vol. XL VII No. 1, pp.56-64. 
32. Ilies, R., Wilson, K. S., \& Wagner, D. T. (2009). The spillover of daily job satisfaction ontoemployees' family lives: The facilitating role of work-family integration. Academy of Management Journal, 52(1), 87-102.

33. Lai Wan, H. (2007), "Human capital development policies: enhancing employees' satisfaction",Journal of European Industrial Training, Vol. 31 No. 4, pp. 297-322.

34. Locke, E. (1976), "The nature and causes of job satisfaction", in Dunnette, M. (Ed.), Handbook ofIndustrial and Organizational Psychology, Rand McNally, Chicago, IL, pp. 1297-349.

35. Le'vy-Garboua, L. and Montmarquette, C. (2004), "Reported job satisfaction: what does it mean?"Journal of Socio-Economics, Vol. 33, pp. 135-51.

36. Lee, C.H. and Bruvold, N.T. (2003), "Creating value for employees: investment in employee development", International Journal of Human Resource Management, Vol. 14,pp. 981-1000.

37. Lee, M. and Koh, J. (2001), "Is empowerment really a new concept?", International Journal ofHuman Resource Management, Vol. 12, pp. 684-95.

38. Lee, (2006), Expectations of employees toward the workplace and environmental satisfaction, Facilities, Vol. 24 No. 9/10, pp: 343-353.

39. Martin, T. N. (1979). A contextual model of employee turnover intentions. Academy of Management Journal, 22(2), 313-324.

40. Martensen, A. and Gronholdt, L. (2001), "Using employee satisfaction measurement to improve people management: an adaptation of Kano's quality types", Total Quality Management, Vol. 2 Nos 7/8, pp. 949-57.

41. Mathieu, J.E. and Zajac, D.M. (1990), “A review and meta-analysis of the antecedents, correlatesand consequences of organizational commitment", Psychological Bulletin, Vol. 2, pp. 171-94.

42. Meyer M (1999). Managing human resources development. An outcomes-based approach. Durban Butterworth Publishers (Pvt) Ltd.

43. Michailova, S. (2002), "When common sense becomes uncommon: participation and empowerment in Russian companies with Western participation", Journal of World Business, Vol. 37, pp. 180-7.

44. Micheal and Sector, (1982), Causes of Employee Turnover: A text of the Mohley, Griffeth, Hand and Meglino Model, Journal of Applied Psychology, 67, 53-59. Lee and Mowday, 1987, Voluntary leaving an organization;an empirical investigation of Steers and Mowday's model of turnover, academy of management journal, 30,721- 743. 
45. Muchinsky, P. M., \& Morrow, P. C. (1980). A multidisciplinary model of voluntary employee turnover.Journal of Vocational Behavior, 17, 263-290.

46. Moss, S., Prosser, H., Costello, H., et al (1998) Reliability and validity of the PAS-ADD Checklist for detecting psychiatric disorders in adults with intellectual disability. Journal of Intellectual Disability Research, 42,173- 183.

47. Nanda R, Browne JJ (1977). Hours of work, job satisfaction andproductivity. Public Productivity Rev., 2. (3): 46-56.

48. Nunnally, J. (1970). Introduction to Psychological Measurement. Toronto: McGraw-Hill Inc.

49. Porter, L.W. and Lawler, E.E. (1968), Managerial Attitudes and Performance, Irwin-Dorsey,Homewood, IL.

50. Petty, G.C., Brewer, E.W. and Brown, B. (2005), "Job satisfaction among employees of a youthdevelopment organization”, Child and Youth Care Forum, Vol. 34 No. 1.

51. Rainey, H.G. (1997), Understanding and Managing Public Organizations, 2nd ed., Jossey-Bass, San Francisco,CA.

52. Rizwan, M., Tariq, M. A., Hussain, S., Rashid, R. M., Hussain, M. S., Khawar, I., H. (2013) Antecedents of Job Stress and Its impact on Job Satisfaction, Asian Journal of Empirical Research, 3(2), 175-190

53. Rizwan, M., Ajmal, Z., Gill, A. S., Hameed, N., Iqbal, S. \& Waqas, A. (2013) Collision of Work with life and its impact on Job Satisfaction. Journal of Basic and Applied Scientific Research, 3(12), 175-184

54. Spector, P. (1997), Satisfaction: Application, Assessment, Causes and Consequences, Sage, London.

55. Sundstrom E., Town JP., Rice RW., March 1994, Osborn DP and Brill M. Office noise, satisfaction andperformance, Environment and Behavior, Vol 26, No.2, 195-222.

56. Sousa-Poza A (2000). Well-being at work. A cross-national analysis of the levels and determinants of job satisfaction. J. Socio-Econ., 29(6):517-538.

57. Snipes, R.L., Oswald, S.L., La Tourc, M. and Armenakis, A.A. (2005), "The effects of specific jobsatisfaction facets on customer perceptions of service quality: an employee-level analysis", Journal of Business Research, Vol. 58, pp. 1330-9.

58. Soler, C.H. (1998), "The relationship of organizational structure and job characteristics to teacher's job satisfaction and commitment (Doctoral dissertation, St John's University, 1998)", Dissertation Abstracts International, Vol. 60, pp. $42-73$.

59. Seibert, S.E., Silver, S.R. and Randolph, W.A. (2004), "Taking empowerment to the next level:A multiple-level model of empowerment, performance, and satisfaction", Academy ofManagement Journal, Vol. 47 No. 3, pp. 332-4. 
60. Tett, R.P. and Meyer, J.P. (1993), "Job satisfaction, organizational commitment, turnoverintention, and turnover - path analyses based on meta-analytic findings", PersonnelPsychology, Vol. 46, pp. 259-93.

61. Thierry, H. (1997), "Motivatie en satisfactie", in Drenth, P.J.D., Thierry, H. and de Wolff, Ch.J. (Eds),Nieuw Handboek Arbeids- en Organisatiepsychologie, Bohn Stafleu Van Loghum, Houten/Diegem, pp. 177-236.

62. Viator, R. E. (2001). The association of formal and informal public accounting mentoring with role stress and related job outcomes. Accounting, Organizations and Society, 26, 73-93.

63. Velthouse, B.A. (1990), "Creativity and empowerment: a complementary relationship", Review of Business, Vol. 12, Fall, pp. 13-18.

64. Wu, L. and Norman, I.J. (2006), “An investigation of job satisfaction, organizational commitment and role conflict and ambiguity in a sample of Chinese undergraduate nursing students", Nurse Education Today, Vol. 26, pp. 304-14.

65. Wilkinson, A. (1998), "Empowerment: theory and practice", Personnel Review, Vol. 27, pp. 40-56.

66. Zikmund, W.R., (1997), Business Research Methods(5th Ed.), the Dryden Press, Fort Worth, Texas. 